\title{
The Developmental Impact of Musical Activities on the Learner
}

\begin{abstract}
This paper focuses on how learners obtain proficiency through musical events employing some Akan traditional songs and Western common songs. The writer contends that learners study better using musical and other allied undertakings. Observation and unstructured interviews were used as instruments to gather primary information from seven basic schools in the Eastern and Central Regions of Ghana. The data showed that growing children embark on a series of experiments but they improve comprehensively when they use homegrown resources (e.g. familiar musical activities in their environments). The recommendation is that educators, caregivers and handlers in various basic schools should work with indigenous and common play songs coupled with related activities in the teaching and learning process.
\end{abstract}

Keywords: children's games, children's music, music education, developmental skills, Akan traditional play songs.

\author{
ERNEST FRANCIS \\ AMPARBIN ${ }^{1}$ \\ ${ }^{1}$ Ernest Francis Amparbin, M.Ed, \\ MPhil (Music Education), PhD \\ candidate, Chief Technician \\ (Music), Centre for Culture and \\ African Studies, Kwame Nkrumah \\ University of Science and \\ Technology, Kumasi, Ghana. \\ Email:amparbinernest@gmail. \\ com \\ Manuscript \\ Received 19th May 2020, \\ Accepted 23rd June 2020, \\ Published online 1st July 2020.
}

\section{INTRODUCTION}

Generally, a musical activity to the African/Ghanaian music educator, could be described as any activity among others which involves clapping and tapping of rhythmic patterns, making dance movements and projection of appealing sounds to the ears through the use of voice and other musical instruments. Miche assert that, "When you are teaching any subject, you teach at many levels at once. However, when you are doing a musical activity, you are teaching listening skills, vocabulary, language structure, cultural awareness, movements, morals and values." 2

These activities undoubtedly are very crucial in the life of every growing child as they acquire the most needed experience to aid their all-inclusive development. Additionally, Miche explained that music is as important for the development of a whole child as it has been in the development of one's own life. She further states that, The importance of music begins in the early years and extends for the entire lifetime, and places emphasis on the fact that music learning begins the moment one jiggles up and down. This experience starts in the womb and by age five; the rhythm of languages, feeling of a beat, keeping time to the music, singing of simple songs had already begun. ${ }^{3}$ In the Ghanaian context, children's musical activities are largely child initiated with little guidance from the adult. At school, teachers of early childhood and basic schools, incorporate musical activities into the teaching and learning process though the frequency is a bit questionable as in recent times teachers do not seem to allocate much time for such activities. Therefore, on recess pupils exhibit a high sense of creativity as they put themselves into groups and engage in different musical activities which technically result in enhancement of retention, coordination, socialization among others.

In Ohene's words, children generally love to play with whatever comes their way. They play all kinds of games using music-oriented activities and learn by sharing ideas. Through games, children develop different skills and attitudes. As a result, one can honor play as an essential means through which children develop physically, mentally, socially, and emotionally. ${ }^{4}$ In this way, they can discover themselves and the world around them. Agreeing with Mackett and Paskins, Amparbin emphasizes the fact that children are usually twofold dynamic when they stepout of home,

\footnotetext{
Mary Miche, Weaving Music in to Young Minds (Delmar: Thomson Learning Incorporated, 2002), 31.

Ibid.

Opokua, Ohene. Fun and Games for Children (Accra: Educational Press and Manufacturers Ltd, 1990), 1.
} 
going all out touching, feeling, observing and interacting with both animate and inanimate objects they set their eyes on. Surely, this is a scenario that depicts- that children learn best when they move to socialize or play. Likewise, the attractions for children staying at home are increasing with the expansion of home entertainment technology, so that children now have opportunities at home to listen to music, play electronic games and watch multi-channel television. ${ }^{5}$ Though, Mackett and Paskins are of the view that these inventions are likely to reduce the relative attractiveness of children who go out to observe, feel, touch, interact and learn from the environment, ${ }^{6}$ however, as both are safe forms of learning, a combination of the two learning processes (i.e., activity-oriented and the use of audio and audiovisuals) are supposed to greatly improve the child's comprehensive development.

Therefore, it is important to consider the activities that children do during recreation and happy moments. This would help to properly organize children's thoughts, hitherto considered a waste of time, for good use and hence the need to investigate the impact of children's activities to assist with teaching and learning. in schools and children's centers.

The musical activities used were grouped as:

\section{HAND CLAPPING GAME}

\section{Ato Kakraba}

This is a game meant for both males and females from age three upwards. The participants form a circle in a standing posture and one of the children (participant) who is automatically given the name "Ato /Ama" gets into the middle of the circle and squats. The rest of the members then sing the song for the game and clap. The lyrics of the song tell how "Ato/ Ama" the little child should behave while in the circle. At the end of the music, the one (Ato) at the center goes to hug one of the members s/he loves or likes. This new person then takes the center position and the game continues till all partakers have had their turn.

\section{Development of listening skills}

As part of the musical activities, children go through series of singing, clapping and chatting with lots of body language. In all these they engage in different modes of listening in order to get their views across to team mates. Nadig, identify three ways to listen and explain as follows;

1. Competitive or combative listening: It occurs when people are more interested in promoting their own point of view than in understanding or exploring the opinions of others. One either listens for openings to speak, or deficiencies or weak points that can be attacked. As one pretends to be alert, he/she eagerly awaits an opening, or formulates a contradiction internally and plans a devastating return that will ruin their discussion and turn them into victory.

2. In passive or attentive listening: This is when people are really interested in listening to and understanding the other person's point of view, they are passively aware and listening, they assume they have heard and understood correctly, but remain passive and do not verify it.

3. Active or reflective listening: This is the most useful and most important listening skill. Active listeners are also genuinely interested in understanding what the other person is thinking, feeling, wanting, or what the message means, and are active in verifying their understanding before responding with a new personal message. They repeat or paraphrase their understanding of the message and reflect it to the sender for verification. This confirmation or feedback process is what separates active listening and makes it effective. ${ }^{7}$

Undoubtedly, in a musical activity such as "Ato Kakarba" where all three modes take place, partakers end up sharpening their listening and communication skills as they frequently join in the action of the game.

\section{Strengthening of aural discrimination}

Naturally, music, whether choral or instrumental builds in children the sense of sound which leads to familiarization of sound sources in the child's environment. Carlton postulates that, the quality of experiences with aural discrimination will affect children's listening, singing, communication and reading skills throughout their lives. Furthermore, she recounted that, Oprah Winfrey once made a plea on a televised programme for parents to sing for their children. ${ }^{8}$ Therefore it seems crucial for parents at home and those working in childcare outfits to pay particular attention to the

\footnotetext{
Ernest Francis, Amparbin." Documentation of some musical plays and their Educational importance to the growing child”. International Journal of Innovative Social Sciences \& Humanities Research 4, no.1 (2016):87-101.

6 Roger, L Mackett., and James, Paskins,. "Children's Phiysical Activity: The Contribution of Playing and Walking." Children and Society, 22, no. 5 (2008): 345-357.

7 Larry Alan Nadig, "Tips on effective listening," Larry Alan Nagid Clinical Psychologist Marriage \& Family Therapist (Healthlinks Accredited), accessed October 9, 2016. http://www.drnadig.com/listening.htm

8 Elizabeth B. Carlton, Learning Through Music: The Support of Brain Research (Redmond: Exchange Press, 2003).
} 
musical needs and hearing discrimination skills of the child. Additionally, Carlton opines that:

Research shows that babies, who are sung to and talked to a lot, develop a greater phonemic awareness and then develop a greater vocabulary. The fetus in the womb is reported to hear all sounds as "musical" through the amniotic fluid. Young children often participate by singing with others, creating "nursery rhymes" on their own as they play. Young children who miss out on these very important interactions are often less expressive and sometimes lag in their speech and may be shy in communicating with others. They may not sing naturally alone or with a group. This is the gentle reminder of music to us that as music tenderly sows the seeds of unfair discrimination, caregivers must nurture this seed through daily musical experiences that include listening, singing, and moving to music. in our child care centers. ${ }^{9}$

Therefore one would say that the musical game "Ato kakraba" when used by teachers could enhance the child's aural discrimination and communication skills.

\section{Enhancement of memory}

In the event where children formally or informally acquire vocabulary, sense of rhythm and sound as they play and be able to apply them in their encounters, are indications that children massively indulge in reasoning and creative sessions as the game ensues. When young children sing, the fundamental constant pulse of the song combined with the active song pushes the brain to reminisce the next part of the song and the next until the end of the song. The process as observed by Carlton, begins as "rote memory" (short term) nonetheless, it evolves into conscious thought and long-term memory as children mature by repeatedly engaging in musical activities they understand and associate with, individually and in groups..$^{10}$

\section{Help children to speak clearly and pay attention}

The idea of rhythm, beat and rhyme as found in music, is also embedded in language. Therefore when children take interest in saying rhymes with beats and manage to stay within the beat, they practically are rehearsing how to pronounce and articulate words. These words basically form the vocabulary of words which will be used in their daily interactions. Carlton observes that, elements of music such as fluency, duration and rhythmic patterns among others, are associated with languages and music holds it all together. ${ }^{11}$ She also states that when children speak, they rhyme and clap constantly; they speak clearly. Further, when teachers encourage children to continue clapping evenly as they sing, no child runs ahead to finish the song first and also sing more in harmony or in tune, they are able to articulate more clearly, therefore, singing is more satisfying for all and sundry. Additionally, the beat or the timing of the music which accompanies musical activities seems to check the attention rate of the children so they can synchronise. In this way, children gradually cultivate the habit and skill of paying attention to every bit of the activities they engage in.

\section{Encourage children's collaboration, thinking, and problem-solving skills}

The numerous activities imbedded in musical games seem to offer children the chance to develop and enrich themselves with acceptable human qualities which will portray them as befitting citizens of the society. This is so because musical activity such as "Ato kakraba" comes with singing, dancing, clapping, squatting and the like, which undoubtedly aid nurturing of children to learn to co-operate, think properly and solve problems that come their way. As recounted by Carlton, opportunities to collaborate in singing games, action songs, and movement to music are active early childhood learning antecedents to thinking, problem-solving, and memory. Additionally, music helps children and adults to stay alert, and it is also an essential element for children who play through all the means by which young children learn. ${ }^{12}$

\section{Enhancement of children's literacy skills}

Musical activities whether formal or informal especially the type meant for children "Ato kakraba" is proposed to have a great deal of influence on the child's literacy development. Indeed the tonal nature of most of the Ghanaian languages such as Akan, Ewe among others, also comprehensively impact on music, such that even a noun "Kofi Ata" a name of Akan male, can be musically interpreted as "d: $r$ : $d$ ". this is to say that phrases and tenses in Ghanaian languages determine their own corresponding musical phrases. Based on her research, one would side with Gromko, who elucidates that, the child receiving music instruction benefits from the emphasis on developing listening skills. When children learn to distinguish fine differences between tonal and rhythmic patterns and to associate their perception

\footnotetext{
Ibid, 18 .

1 Ibid

1 Ibid

2 Ibid
} 
with visual symbols, they benefit not only musically, but also in the skills related to sound processing that is shown necessary for reading. She states again that the finding coincides with the "near transfer theory" that tends to win due to the similarities in brain function between music and phonemic mindfulness. ${ }^{13}$

\section{JUMPING GAME}

\section{Kwasi Maame e "raswota"}

The organization of this musical game is normally done by both male and female children of about four years and above. In this game children stand, hold hands and form a big circle (the size of the circle usually depends on the number of participants). One of the children is unanimously selected to be a leader who will set the game rolling. The leader sings the game song using the day born names of the participants' whiles they also respond after each phrase as they swing their held hands. For instance, the leader intones "kwasi mame e raswota" (Kwasi-Sunday male born) then the rest respond "yee yee raswota", this goes on till the leader runs through the day born names of all members forming the team. When the number of participants is huge, the leader normally goes through all the day born names just to cover all and sundry. The leader then ends with the phrase, "oye d\&; ssikyere w'om" then the responds is "yaa yaa ya e sikyere w'om oya". Whiles participants respond, they hold hands firmly and jump either clockwise or anti-clockwise but in all these, care is taken so that no one falls and get hurt. The singing and jumping last for a while depending on the leader's discretion then the next person is asked to restart the activity.

Note: 1. Yee! Yee!, Yaa! Yaa! Oya!- are peculiar expressions of the game.

\section{Lyrics of the game song}

$\begin{array}{lll} & \text { Akan } & \text { English } \\ \text { Cantor: } & \text { Kwasi mame e raswota } & \text { kwasi's mother's rice water (rice-porridge) } \\ \text { Responds: } & \text { yee yee raswota } & \text { yee yee rice water } \\ \text { Cantor: } & \text { kwadwo mame e raswota } & \text { kwadwo's mother's rice water } \\ \text { Responds: } & \text { yee yee raswota } & \text { yee yee rice water } \\ \text { Cantor: } & \text { kwabina mame e raswota } & \text { kwabina's mother's rice water } \\ \text { Responds: } & \text { yee yee rsawota } & \text { yee yee rice water } \\ \text { Cantor: } & \text { kweku mame e raswota } & \text { kweku's mother's rice water } \\ \text { Responds: } & \text { yee yee raswota } & \text { yee yee rice water } \\ \text { Cantor: } & \text { Yaw mame e raswota } & \text { Yaw's mother's rice water } \\ \text { Responds: } & \text { yee yee raswota } & \text { yee yee rice water } \\ \text { Cantor: } & \text { kofi mame e raswota } & \text { kofi's mother's rice water } \\ \text { Responds: } & \text { yee yee raswota } & \text { yee yee rice water } \\ \text { Cantor: } & \text { kwame mame e raswota } & \text { kwame's mother's rice water } \\ \text { Responds: } & \text { yee yee raswota } & \text { yee yee rice water } \\ \text { Cantor: } & 4 y 1 \text { dl; lsikyere w'om } & \text { its sweet there is suger in it } \\ \text { Resp: } & \text { yaa yaa ya lsikyere w'om Oya. } & \text { Yaa yaa ya suger in it Oya. }\end{array}$

3. Days of the week and their Akan names applicable to the game

\begin{tabular}{|l|l|l|}
\hline Day & Male & Female \\
\hline Sunday & Kwesi / Akwasi & Akosua / Akos \\
\hline Monday & Kwadwo / Kojo & Adwoa / Adjoa \\
\hline Tuesday & Kobina / Kwabena & Abena \\
\hline Wednesday & Kweku & Akua \\
\hline Thursday & Yaw & Yaa \\
\hline Friday & Kofi / Fiifi & Efua / Afua \\
\hline Saturday & Kwame / Kwamena & Ama \\
\hline
\end{tabular}

\footnotetext{
13 Joyce Eastlund Gromko, "The effect of music instruction on phonemic awareness in beginning readers." Journal of College reading and learning, 53, no. 3 (2005):199-209
} 


\section{Development of listening skills}

The organization of the musical activity enable children to get involved in series of actions such as singing, dancing, clapping, jumping and articulation of words which go a long way to aid the shaping of the child. In the area of listening, children equip themselves with the ability to analyse old and new words, phrases and tenses as well as sound which come to them by way of play and act accordingly.

\section{Strengthening of aural discrimination}

Musical games are one of the numerous medium through which children build and fortify their skill of aural discrimination. This is possible because through play, children are introduced to vocabulary, pronunciation, rhythm, pitch and sound which guide their comprehension of communication and demeanor towards one another.

Although Chomsky argues that the contribution of a learner from the environment is insufficient to account for the speed at which people acquire language, he also affirms that people are born with knowledge that allows them to acquire language and allows the individual to structure any language and obtain it. ${ }^{14}$ In similar manner, Krashen states through his "input" and "affect filter" hypotheses, that a new unknown vocabulary is acquired when its meaning is clarified to the student by providing additional linguistic support, such as illustrations, actions, photos and regalia. ${ }^{15}$ Therefore, to help enhance children's aural interpretation, it pays to engage them in interactive sessions such as musical games, drama just to mention.

\section{Enhancement of memory}

The idea of improving the memory properties of children can start at an early age and can affect the child throughout his or her life. The ability to remember and recall information, details, and even people's names can go a long way in helping a child or even an adult be more successful in school, work, and daily life. Therefore, it is incumbent on parents, caregivers, and teachers to encourage children to improve their memory through the use of music games, such as birth names, month names, names of the year, and other memory test activities, related to music to help improve their memory status.

Renata is of the view that, cognitive development is the way a child learns and solves problems. As a child develops cognitively, he/she gains knowledge of the environment and improves the ability to interact with it. She explains further that cognitive development includes memory, concentration, attention, perception, imagination, and creativity. ${ }^{16}$ Indeed, when children reach certain developmental milestones in their lives, they acquire various cognitive skills and consequently, parents and teachers can use learning activities, for instance musical games, playing of musical instruments to promote their children's cognitive growth.

\section{Help children to speak clearly and pay attention}

As children partake in musical games, they come across numerous challenges in the form of rhythmic interpretations, pitch, projection of voice, coordination of body parts in movements, pronunciation of words and their spellings and intonation of phrases and tenses (speech). The child's frantic effort to surmount these challenges as they play, go into shaping of language and its usage in their day-to-day interactions. With this skill, children learn to critically consider or better still pay much attention to the kind of words and sentences they use even at their level to send home their intentions and expect a responds (whether favorable or unfavorable).

\section{Encourage children's collaboration, thinking, and problem-solving skills}

Musical games create the avenue for children to learn and adopt the habit of co-operating with one another as they sing and dance, play different instruments in harmony, and most importantly being able to organize the activity and carry it through to the end. In the same manner, they take up leadership roles as part of the game and give orders which bind the rest and they likewise obliged and give result. The participants of the game occasionally may agree to disagree with themselves on suggestions made, all for the betterment of the game. To a large extent, the back and forth arguments get the children putting on their thinking caps and problem solving skills in order to achieve result as they struggle to go through the programme successfully.

\section{Improving children's literacy}

Reading and writing ability, as Feret and Smith explains, enable people to function fully in society. They state that the

14 Noam Chomsky, Aspect of the Theory of Syntax.Cambridge: Mass. Mit. Press. 1965.

15 Stephen Krashen, Stephen. "We Acquire Vocabulary and Spelling by Reading: Additional Evidence for the input Hypothesis." Modern language journal, 73, no.4 (1989): 440-464.

16 Rebecca Renata, “Activities to Promote Children's Cognitive Development”, accessed Jult 30, 2016.

http://www.ehow.com/info_7813000_activities-promote-childrens-cognitive-development.html. 
ability to read and write basically represents literacy, adding that the process of scanning letters or symbols for meaning and registering thoughts in a somewhat permanent way, listening and speaking, as well as thoughtful consideration of sound, if it is musical or verbal is the property of literacy. ${ }^{17}$ In the appearance of the musical work being discussed, the child has a better chance of acquiring the basic characteristics of becoming a literate individual when communicating verbally, musically, and through actions and movements to fully express themselves to each other.

\section{CONCLUSION}

The paper has shown that musical activities for children have a positive impact on the growth process of the individual. It shows that musical activities are highly instrumental in improving the child's thinking and problem-solving skills, retention and auditory discrimination, as well as listening and literacy skills. Consequently, a treacher or anyone who wishes to employ any of the activtities in the classroom, must study the write-up in relation to the general and specific objectives of the intended lesson and professionally incorporate the musical activtities into the lesson such that by the end of the lesson, the objectives would be achieved (eg. The jumping game "rice water" could be used to teach and emphasise days of the week). Agreeably, the activities discussed in the paper, effectively contribute to the all-round development of the learner as it impacts on the domains to induce easy adjustment to the changing order of the world and its intricacies.

\section{BIBLIOGRAPHY}

Amparbin, Ernest Francis." Documentation of some musical plays and their Educational importance to the growing child”. International Journal of Innovative Social Sciences \& Humanities Research 4, no.1 (2016):87-101.

Carlton, Elizabeth B. Learning Through Music: The Support of Brain Research. Redmond, VA, Exchange Press, 2003.

Chomsky, Noam. Aspect of the Theory of Syntax.Cambridge: Mass. Mit. Press.1965.

Feret, Alice J., and Smith, Judith J. "Literacy Skills in Music class: Tool for Pre-Service Teacher Growth". Vision of research in music education.Accessed September 23, 2016. http://www-usr.rider.edu/ vrme/ v15n1/visions/Literary\%20Skills\%20in\%20Music\%20Class.Feret\%20and\%20Smith.pdf

Gromko, Joyce Eastlund. "The Effect of Music Instruction on Phonemic Awareness in beginning Readers." Journal of College reading and learning, 53, no.3 (2005): 199-209

Krashen, Stephen. "We Acquire Vocabulary and Spelling by Reading: Additional Evidence for the input Hypothesis." Modern language journal, 73, no.4 (1989): 440-464.

Mackett, Roger L., and Paskins, James. "Children's Phiysical Activity: The Contribution of Playing and Walking." Children and Society, 22, no. 5 (2008): 345-357

Miche, Mary. Weaving Music in to Young Minds. Delmar: Thomson Learning Incorporated, 2002.

Nadig, Larry Allan. "Tips on Effective Listening." Larry Alan Nagid Clinical Psychologist Marriage \& Family Therapist (Healthlinks Accredited). Accessed October 9, 2016. http://www.drnadig.com/listening.htm

Ohene, Opokua. Fun and Games for Children. Accra: Educational Press and Manufacturers Ltd, 1990.

Renata, Rebecca. “Activities to promote children's cognitive development." ehow.com. Accessed July 30, 2016. http://www.ehow.com/info_7813000_activities-promote-childrens-cognitive-development.html.

\footnotetext{
17 Alice J. Feret \& Judith J. Smith, "Literacy Skills in Music class: Tool for Pre-Service Teacher Growth," Vision of research in Music Education, accessed September 23, 2016,

http://www-usr.rider.edu/ vrme/v15n1/visions/Literary\%20Skills\%20in\%20Music\%20Class.Feret\%20and\%20Smith.pdf
} 